\title{
Floor of Mouth Adenoid Cystic Carcinoma
}

National Cancer Institute

\section{Source}

National Cancer Institute. Floor of Mouth Adenoid Cystic Carcinoma. NCI Thesaurus. Code C8180.

An adenoid cystic carcinoma of the oral cavity that arises from the floor of the mouth. 